\title{
BIBLIOGRAPHY
}

\author{
Archives
}

\section{Barbados Archives}

Government House (GH) 3/4/3-5, LF/S/40 (i) and (ii). Scheme of organisation against civil disturbances, 1919-22.

GH3/5/1-8, LT Series. Unrest in West Indies, 1919-25, 1939.

GH3/5/49, Mis/G/49. Precautions against trouble at Glendairy, 1937-38.

GH3/6/3, Mis/G/24. Bishop Jack of the Episcopal Orthodox Church, 1925.

GH3/6/4, Mis/G/41. Publications addressed to the working class, 1932-33.

GH3/6/5, Mis/G/42. Movements of Communist agents, 1933.

GH3/6/7, Mis/G/48. Clement Payne, 1937.

GH3/6/10, Mis/G/42. Telegram from Governor of British Guiana to Governor of Barbados.

GH3/6/10, Mis/G/51. G. H. Adams' interview with Secretary of State, 1937.

$\mathrm{GH} 3 / 6 / 10, \mathrm{Mis} / \mathrm{SS} / 41$. Intelligence reports.

GH3/7/11, Mis/SS/25. Governor's report on affairs in Barbados, 1928-32.

GH3/7/11, Mis/SS/48, Secret circular from Cunliffe Lister

GH3/7/20, Mis/SS/41. Gordon Bell of the Forum Club.

$\mathrm{GH} 3 / 7 / 25$, Mis/SS/48. Refusal of passport facilities for India to members of revolutionary organisations, 1934

GH3/7/26, Mis/SS/49. Foreign wireless propaganda, 1935.

GH3/7/26, Mis/SS/54. Grant of certificate of naturalisation of alien political, 1936.

$\mathrm{GH} 3 / 7 / 31, \mathrm{Mis} / \mathrm{SS} / 55$. Co-ordination of police work in West Indies re. aliens, 1936-37.

GH3/7/37, Mis/SS/65. Activities of Empire Movement, 1938.

GH3/7/39, Mis/SS/68. Emancipation centenary, proposed message from King, 1938. GH3/7/40, Mis/SS/69. Proposed visit by Hile Rigaudias to investigate conditions of negro workers, 1938.

GH3/7/44, Mis/SS/75. Independent Labour Party pamphlet, 1938

GH3/7/46, Mis/SS/78. Labour from BWI for improvements to Panama Canal, 1939-40.

GH3/10/1, W/S/3 pt 1 . Special powers of Executive in time of war, 1939.

$\mathrm{GH} 3 / 10 / 5, \mathrm{~W} / \mathrm{S} / 8$. Dissemination of information during war.

GH4/36-38. Secret detective reports.

GH4/52. BWI emigrants in South and Central America.

GH4/109. Disturbances, 1937.

GH4/110. Disturbances, 1937.

GH4/111. Disturbances, 1937.

GH4/112. 1937 Lightermen and stevedore's strike.

GH4/113. Plans for dealing with disturbances.

GH4/116. Proposal to settle surplus population in Nevis.

GH4/117. West Indian Conference, 1944.

GH4/118. Committee to examine five-year plan.

GH4/120. Recording assessments of intelligence.

GH4/122. Security of land tenure.

GH4/123. Peasants' loan bank.

GH4/125. Emigration. 


\section{B IB LIOG R A PHY}

GH4/126. Governor's address at opening of legislative session, 1956-58.

GH5/1-8. LT (Labour Trouble) Series, 1919-1925, 1939.

GH Confidential Series. CSO minute paper C104 (vol. 1), C256, C386, C412, C488, C579, C689, C864/3.

CSO Confidential Series (petitions, 1937): Aa982, Ac1350, Ad989, Ae369, Af43, Ah363, Am985, Ap367, Ap990, Ar987, As565, Ep64, Ga443, Gb288, Gb288, Gb302, Gb494, Gb60, Gb63, Gc294, Gc493, Gc65, Gd297, Gd69, Gf59, Gg60, Gg60, Gh442, Gh455, Gi259, Gj62, Gm61, Gr 263, Gs445, Gs57, Gs68, Gw289, Gw291, Hb650, Hw249.

Correspondence and enclosures between Colonial Secretary and Colonial Office (various untitled, 1937-1960), GHQ: C20 (vol. 1), C25, C26, C30, C33, C39 (vol. 1), C42 (vol. 2), C42/S/1, C42/S5/1, C42/S5/3, C42/S5/12, C42/S5/14, C42/S5/17 (vol. 1), C42/S11, C43, C44, C49/51, C51, C60 (vol. 1), C70, C84, C86, C91, C93, C105, C113 (vols 1-3), C115 (vol. 2), C134, C148, C154, C185 (vol. 10), C199, C223, C226, C238, C240, C254, C262, C268, C273, C349, C376, C378, C401, C409, C416, C418, C428, C445, C455, C461/9, C461/9/1, C590, C602, C648, C649, C726.

Barbados. Criminal Statistics, 1938.

Minutes of Poor Law Guardians for the Parish of St George, selected years, 1937-59.

Legislative Council Debates, selected years, 1937-66.

Legislative Council Minutes, selected years 1937-66.

House of Assembly Debates, selected years, 1937-66.

House of Assembly Minutes, selected years 1937-66.

Official Gazette, 89 (26 Apr. 1954).

\section{University of the West Indies \\ Federation of the West Indies Archives}

FWI FS SFC1. Federal Secretariat Standing Federation Committee - First Meeting, Barbados.

FWI FS SFC3. Federal Secretariat Standing Federation Committee - Second Meeting, Jamaica.

FWI FS SFC5. Federal Secretariat Standing Federation Committee - Fourth Meeting, Trinidad.

FWI GG GA41. Future of the Federation.

FWI PM GA163. National song for the West Indies.

FWI PM GA172. Undesirable publications.

\section{The National Archives}

BW2/89. British cultural propaganda in West Indies, 1939-40.

BW17/8. British Council, Barbados, 1941-46.

BW130/3. British Council art exhibitions and activities, 1950-53.

CO28/311/15. Affairs in Barbados: Despatch from the Governor, W. C. F. Robertson, Sept. 1932.

CO28/313/19. Affairs in Barbados: Despatch from the Governor, Sir Mark Young, Oct.Dec. 1934.

CO28/316/7. Affairs in Barbados: Despatch from the Governor, Sir Mark Young, June 1936. 


\section{B IB LIOG R A PHY}

CO28/319/8. Civil disturbances: Reports and despatches, July 1937 - Feb. 1938.

CO28/321/12. Report of the Disturbances Commission, Jan. - Dec. 1938.

CO28/324/11. Events after Report of the Disturbances Commission, Dec. $1938-$ Feb. 1940.

CO28/325/2. Report on labour situation by Major G. Orde-Browne.

CO28/325/12. Emigration, Oct. 1939 - June 1940.

CO28/326/6. Colonial Development Fund, Feb. - June 1940.

CO28/326/10. Emigration: Barbadians in French Guyana, Apr. - May 1940.

CO28/327/13. Affairs in Barbados: Despatch from the Governor, Sir G. Bushe, Mar. - Jun 1942.

CO28/327/14. Affairs in Barbados: Despatches from the Governor, Sir G. Bushe, June 1942 - Jan. 1944.

CO28/328/7. Unemployment problem, June 1941 - Jan. 1942.

CO28/328/8. Emigration schemes, Apr. 1943 - Jan. 1944.

CO28/328/10. Report on unemployment by labour officer, G. Perrin, July 1941 - Nov. 1943.

CO28/328/15. Situation in Barbados, Jan. 1941 - Jan. 1942.

CO28/329/7. Colonial Development and Welfare: Memorandum on social welfare, Sept. 1942.

CO28/329/9. Colonial Development and Welfare: Ante-natal and infant welfare services, Aug. 1941 - Nov. 1942.

CO28/329/13. Colonial Development and Welfare: Extension of women's work bureau, Jan. 1943 - July 1944.

CO28/330/7. Broadcasts by the Governor, G. Bushe, Apr. - Aug. 1943.

CO28/332/4. Affairs in Barbados. Despatches from the Governor, Sir G. Bushe, Dec. 1943 - Jan. 1945.

CO28/332/5. Affairs in Barbados. Despatches from the Governor, Sir G. Bushe, Dec. 1944 - Mar. 1946

CO28/332/6. Affairs in Barbados. Report on visit by K. O. Roberts Wray, Oct. 1944.

CO28/332/16. Strikes and labour disputes, Jan. 1943 - Nov. 1944.

CO32. Barbados, Government Gazettes, 1867-1989.

CO137/847/5. Request from Harold Moody to Secretary of State for meeting, re. civil liberties, 29 Nov. 1941 - 7 Jan. 1942.

CO295/606/4. Communist activity in British West Indies, 22 Mar. - 24 Jun. 1938.

CO298/47. Vital statistics: Deputy Registrar-General's report for the year 1890 .

CO31/107. Census of Barbados, 1921.

CO318/427/11. Trinidad and Barbados riots, 1937.

CO318/432/2. Marcus Garvey and connected associations, 1938.

CO318/434/8. Visit of Major Orde-Browne to West Indies, 1938.

CO318/435/2. Racial tensions in Jamaica, 1938.

CO318/439/8. Lord Moyne's Broadcast 1939-40.

CO318/439/12. Report of Major Orde-Browne's visit to West Indies, 1939-40.

CO318/443/7. Report on relief works, 1940-41.

CO318/443/9. West India Committee reports, 1940.

CO318/444/18. Medical and public health, Barbados, 1940.

CO318/445/7. Praedial larceny, 1940-41.

CO318/451/13. Comptroller's despatches to the Governor, Barbados, 1941.

CO318/451/14. Comptroller's despatches to the Governor, Barbados, 1942-43.

CO318/454/4. Barbados, 1942-43.

CO318/455/4. American interest in British West Indies policy, 1942.

CO318/484/1. Constitution and Federation: setting up Closer Association working party, 1947. 


\section{B I B LIO G R A P H Y}

CO318/485/4. Standing Closer Association Committee, West Indian Governors, 194849.

CO323/1518/9. International Trade Union Committee of Negro Workers, 1937.

CO323/1518/12. Marcus Garvey. Universal Negro Improvement Association, 1937.

CO323/1742/2. Colonial press summaries, 1940.

CO537/1265. Caribbean defences, naval arrangements, 1943-46.

CO537/1266. Employment of West Indian contingent in active theatre of operation, $1945-46$.

CO537/1682. Strikes and labour disputes, 1945-46.

CO537/2247. Intelligence and situation reports, 1946-47.

CO537/2259. Caribbean Labour Congress, 1947.

CO537/2779. Review of security, Communist infiltration, Barbados, 1948.

CO537/6126. Political situation reports, 1948-49.

CO537/6127. Political situation reports, 1949-50.

CO537/6523. West African security: George Padmore, 1950.

CO537/7371. Political situation reports, 1951.

CO565/11. Barbados register of correspondence, 1935-37.

CO859/77/2. Cultural development, West Indies, 1941-43.

CO859/179/3. Reports by C. L. Stuart and Lord Listowel on housing, education and community development, 1950-51.

CO859/507. Report from Barbados, 1955-56.

CO859/975. West Indies, 1957-58.

CO875/5/17. Reports on public opinion, 1942.

CO875/11/11. Fabian Colonial Bureau, 1940-41.

CO875/20/1. Propaganda to West Indies, 1940-45.

CO875/45/2. Activities in Barbados and Windward Islands, estimates, 1949-50.

CO875/45/3. Activities in Barbados and Windward Islands, expenditure, 1948.

CO875/62/1. Barbados, 1951.

CO876/155. West Indian Students Union, London, 1950.

CO876/156. West Indian Students Union, London, 1951-52.

CO936/674. Brief for West Indies Federation meeting between Prime Minister and US President, 1961.

CO950/30. Reports to WIRC by League of Coloured People, 1938-39.

CO950/612. H. A. Vaughan, Memorandum of Evidence, West India Royal Commission.

CO950/566. Office memorandum: Social welfare, 1938-39.

CO950/569. Note by Governor on emigration from Barbados, 1938-39.

CO950/570. Memorandum of evidence: Clergy and ministers, 1938-39.

CO950/571. Memorandum of evidence: Dr J. Hutson, 1938-39.

CO950/572. Office memorandum: Labour questionnaire, 1938-39.

CO950/576. Memorandum of evidence: O. M. Grant, 1938-39.

CO950/582. Memorandum of evidence: Mr I. Lovell, 1938-39.

CO950/583. Office memorandum: Population, 1938-39.

CO950/590. Memorandum of evidence: Mr S. M. King, 1938-39.

CO950/605. Memorandum of evidence: Mr W. A. G. Crawford, 1938-39.

CO950/607. Memorandum of evidence: Leeward Workers Association, 1938-39.

CO950/611. Memorandum of evidence: Mr K. H. G. Ballou, 1938-39.

CO950/617. Analysis of occupation of voters at 1938 elections, 1938-39.

CO950/906. Suggested emigration of poor whites from Barbados to Australia, 1938-39.

CO950/919. Barbados, 1938-39.

CO951/69. West Indian Students Union.

CO968/81/4. Recruitment of women, West Indies, 1943.

CO968/300. West Indies 1952-53. 


\section{B IB LI O G R A PHY}

CO1017/214. Barbados 1953.

CO1027/272. Broadcasting in Barbados, 1957-58.

CO1027/363. Publicity for Secretary of State's visit to West Indies, 1962.

CO1027/675. Barbados, 1963-65.

CO1027/713. Barbados, 1964-65.

CO1031/131. Barbados, 1951-53.

CO1031/504. Development plan, Barbados, 1952-53.

CO1031/712. Barbados, policy arising from conference, 1952.

CO1031/915. Barbados, 1952-53.

CO1031/1296. Results of General Election 1956, 1956-57.

CO1031/1342. Reports from Governor of Barbados, 1956.

CO1031/1350. Constitutional development, Barbados, 1956.

CO1031/1463. Racial discrimination in Barbados, 1954-56.

CO1031/1810. Monthly political reports, Barbados, 1954-56.

CO1031/1881. Commission of Enquiry to investigate prison disorders, Barbados, 195657.

CO1031/1964. Measures to alleviate over-population in Barbados, 1954-56.

CO1031/2781. Family Planning Association of Barbados, 1957-58.

CO1031/2863. Report on neglected children and delinquency, Barbados, 1957.

CO1031/3365. Establishment of regional council of ministers, 1962.

CO1031/3728. Monthly reports, Barbados, 1960-62.

CO1031/3729. Monthly reports, Barbados, 1962-63.

CO1031/4175. Subversive activities in West Indies planned by Haitians, Cubans and Dominicans, 1960-62.

CO1031/4272. Attitude towards the Federation, Barbados, 1960-62.

CO1031/4324. Briefs for Sir Grantley Adams' meetings with Lord Perth and Secretary of State, 1961.

CO1031/4764. Intelligence reports, Barbados, 1963-64.

CO1031/5051. Visit of Lord Taylor to Barbados, 1964.

CO1031/5061. Barbados, Constitutional development, 1966.

CO1031/5124. Barbados Independence: Financial arrangements, 1966.

CO1042/161. Unification of medical services, 1945-1952.

CO1042/239. Friendly Societies of Barbados, 1948-49.

CO1042/280. Survey of peasant holdings, 1943-44.

CO1042/285. Barbados Museum and Historical Society, 1942-50.

CO1042/288. Labour and trade unions, 1941-52.

FO371/155748. Talks between UK and US on West Indian Independence, 1961.

FO371/155752. US policy towards West Indies Federation, 1962.

FO371/155753. US policy towards West Indies Federation, 1961.

FO371/155754. US policy towards West Indies Federation, 1961.

FO371/155755. US policy towards West Indies Federation, 1961.

FO371/161997. West Indies Federation, 1962.

FO371/161998. West Indies Federation, 1962.

KV2/1824. C. L. R. James, Jan. 1932 - Dec. 1941.

KV2/1825. C. L. R. James, Jan. 1941 - Dec. 1954.

KV4/275. Intelligence organisation in the Windward Isles, Jan. 1915 - Dec. 1939.

MEPO38/9. Nancy Cunard. Negroes Welfare Association, 1932-47.

MEPO38/91. International African Services Bureau, reports, 1937-65.

PREM11/3623. Briefs and records of meetings, Prime Minister with Sir Grantley Adams, 1959-61. 


\section{B IB LIOG R A PHY}

\section{National Archives and Records Administration (Maryland)}

Foreign Relations of the United States, Central Decimal Files, 1945-60 (consular reports/despatches from West Indies and Barbados): 841E.00/8-1051, 841E.06/10-1854, 841E.062/8，841E.411/1-2154，841G.06/2，844B.91/6，844C.00/1-2045，844C.00/2-945， 844C.00/3-2848, 844C.00/5-1846, 844C.00/11-1546, 844C.50/9-2547, 844C.76/10, 844C.5043/4, 844C.5043/9, 844C.504/5-2048, 844C.504/5-2347, 844D.00/5, 844D.00/8, 844F.504/6, 844G.00/11, 844G.00/13, 844G.00/14, 844G.00/17, 844G.00/18, 844G.00/21, $844 \mathrm{G} .00 / 26,844 \mathrm{G} .00 / 27$

\section{Political and Economic notes, Barbados}

741E.00/1, 741E.00/3, 741E.00/5, 741E.00/6-1754, 741E.00/7, 741E.00/9, 741E.00/12, 741E.022/5, 741E.5/1-654, 741F.5/6-2260, 741G.00/1-3156, 741G.00/2-1755, 741G.00/3, 741G.00/5-756, 741G.00/6-155, 741G.00/8-1855, 741G.00/9, 741G.00/11, 741G.00/12

\section{Schomburg Center for Research in Black Culture}

Richard B. Moore papers.

\section{Taussig papers}

Box 33. Report of the West Indian Conference, Second Session, Feb. 21 - Mar. 13, 1946; 'Report to the President and Secretary of State on the First West Indian Conference held in Barbados, B. W. I., March 21-30, 1944, under the auspices of the Anglo-American Caribbean Commission'.

Box 34. The Caribbean Commission, The Caribbean Islands and the War, 1943; Sugar and the Caribbean Problem for 1942-43-44, Appendix IV, 'Land-water supply route, the British West Indian Schooner Pool'.

Box 35. 'Summary of visit of Charles W. Taussig, United States Chairman of the AngloAmerican Caribbean Commission to London - Dec. 9-19, 1942'; 'Discussion between Colonel Oliver Stanley, Secretary of State for the Colonies, and Charles W. Taussig on the political problems in the British West Indies'; 'Report of the United States Commission to study social and economic conditions in the British West Indies, appointed by the President of the United States on November 13, 1940'.

Box 43. 'Conversation with Sir Arthur Creech Jones, Secretary of State for the Colonies', 24 Oct. 1947.

Box 45. Copy of Sir Frank Stockdale, 'The work of the Caribbean Commission', International Affairs (Apr. 1947).

Box 46. 'Memorandum for Mr Taussig', 19 Dec. 1940; Letter from American Embassy, Havana, to Sumner Welles, 20 May 1942; 'Conclusions of Supply Officers' Conference'.

Box 47. 'A.A.C.C. Caribbean land-water emergency route and organization and utilization of small ships under 1000 tons'; Operating Plan of the West Indies Schooner Pool.

Box 48. Department of State, Memorandum of Conversation, 'The character of regional commissions', 23 Jan. 1945; Memorandum from Phyllis L. Le Roy on Stockdale, 28 Feb. 1945.

Box 49. 'Record of conversations between Colonel Oliver Stanley and Mr Charles W. Taussig, on matters pertaining to the Anglo-American Caribbean Commission, Jan. $161945^{\prime}$.

Box 52. Excerpt from Minutes, Secretary Staff Committee, 24 July 1945, Expansion of 


\section{B IB LI O G R A PHY}

Anglo-American Caribbean Commission.

Box 54. 'Plan to establish a system to assure and to control necessary supplies to the

Caribbean area'; Letter to the President from Sumner Welles, 12 June 1942.

\section{Tugwell papers}

Box 11. Letter from R. G. Tugwell to Harold L. Ickes, 10 Apr. 1941.

\section{Reports}

Annual Report of the British Council in Barbados, 1945.

Annual Report on the Social and Economic Progress of the People of Barbados, 1936-37, 1937-38, 1938-39 (London: HMSO).

Barbados. Annual Report on Poor Relief for the year 1931.

Barbados: Department of Medical Services. Annual Report of the Director of Medical Services for the Year 1936-37.

Barbados: Department of Medical Services. Annual Report of the Director of Medical Services for the Year 1944-45.

Barbados: Department of Medical Services. Annual Report of the Director of Medical Services for the Year 1957-58.

Barbados: Department of Medical Services. Annual Report of the Director of Medical Services for the Year1964-65.

Barbados Emigration Commission Report, 1895.

Chenery, J. W. B. Report of Commission of Enquiry into St Andrews Almshouse, 1955.

Deane Commission. The Barbados Disturbances 1937. Review - Reproduction of the Evidence and Report of the Commission. Compiled by W. A. Beckles, J. P. (Bridgetown, Advocate Co. Ltd., 1937).

Development and Welfare in the West Indies. Annual Reports, 1940-58 (London: HMSO).

Development and Welfare in the West Indies. Barbados: Survey of Peasant Holdings, 1943. (London: HMSO)

Platt, B. S. Nutrition in the West Indies (London: HMSO, 1946).

Report of the Anglo-American Caribbean Commission to the Governments of the United States and Great Britain 1942-43 (Washington, D.C., 1943).

Report of Barbados Arts Council for the Year 1959-1960, 1962-1963.

Report from Chief Medical Officer, Barbados, to Colonial Secretary, 13 Apr. 1940.

Report of the Committee Appointed to Consider and Report on the Question of Introducing a Scheme of Old Age Pensions in Barbados. Appointed by the Government in 1936 and laid before the House of Assembly, 26 Jan. 1937.

Report of the Committee Appointed to Consider and Report on the Question of Nutrition in Barbados, 1936. Laid as supplement to Official Gazette, 7 Oct. 1937.

Report on Elementary Education for the Year 1936. Laid before the House of Assembly, 12 Oct. 1937.

Richardson, J. Henry. Report of Inquiry into Social Security in Barbados (Bridgetown, Barbados, Sept. 1954).

Skeete, C. C. The Condition of Peasant Agriculture in Barbados (Barbados: Department of Science and Agriculture, 1930).

Taussig, Charles W. Report of the United States Commission to Study Social and Economic Conditions in the British West Indies, Appointed by the President of the United States on November 13, 1940.

Taussig, Charles W. Report to the President and Secretary of State on the First West Indian Conference Held in Barbados, B. W. I., March 21-30, 1944, under the 


\section{B IB LIOG R A PHY}

Auspices of the Anglo-American Commission (Washington, 13 May 1944).

The Caribbean Islands and the War: A Record of Progress in Facing Stern Realities

(Washington: United States Government Printing Office, 1943).

West India Royal Commission Report (London: HMSO, 1945).

\section{Censuses}

Census of the Colony of Barbados, 1891, 1921.

Census of the Colony of Trinidad and Tobago, 1891, 1931.

Census of the Colony of Jamaica, 1911.

West Indian Census, 1946.

\section{Primary Sources}

\section{Printed}

Advocate, The (selected issues, 1961-66).

Anti-Imperialist Review (1931).

Bajan (1953-54).

Barbados Advocate (selected issues, 1937-61).

Barbados Daily News (selected issues, 1964).

Barbados Electors' Association Manifesto and Policy (1951).

Barbados Labour Party Manifesto (1944).

Barbados Observer (selected issues, 1964-66).

Bim (1942-53).

Caribbean Review (1940).

Federal Magazine (1959).

Forum (Dec. 1931 - Mar. 1934; Dec. 1943 - Dec. 1945).

Imperial Review (June 1956).

International African Opinion

International Negro Workers' Review (1931).

Jamaica Progressive League of New York, A Social and Economic Programme for Jamaica

(New York, 1938).

Jemmott, C. 'Emigration and Barbados', West Indian American, Nov. 1927.

Migration and the Negro Population of New York compiled by Workers of the Writers

Program of the Work Projects Administration in New York City for 'Negroes of New

York'. Writers' Program (New York, N.Y., 1939-40)

Miller, Freddie. Labour Believe (BLP discussion pamphlet, Nov. 1951).

Negro Worker (1931-37).

Negro World (1929-33).

O'Meally, Jaime. Why We Demand Self-Government (New York, 1938).

Onward: The Manifesto of the Barbados Labour Party (1961).

Operation Takeover: Manifesto of the Democratic Labour Party (1961).

Outlook, The (1931).

Payne, C. My Political Memoirs of Barbados (Port-of-Spain: Payne, 1937).

Programme and Policy of the Barbados Labour Party: Manifesto (1966).

Roberts, W. A. Self Government for Jamaica (New York, 1936).

'The negro immigrant in New York', Writers' Programme of New York (26 June 1939).

The State of Politics in Barbados and the Needs of the People (People's Progressive

Movement, 1966).

Victory Magazine (1944). 


\section{B IB L IO G R A PHY}

We Now Have A Country: Manifesto of the Democratic Labour Party (1966).

West Indian American (1927).

West Indian Organizer

West Indian Review (1941-42).

West Indies Federal Labour Party: Election Manifesto (1958).

Weymouth Magazine (1943-49).

\section{Oral}

Barbados Nation Project (2006). Recordings deposited with Barbados National Oral History Project.

Barbados Migration Project (1997). Recordings and transcripts deposited with National Life Story Collection of National Sound Archive, British Library.

Barbados Tenantry Project (1990). Recordings and transcripts deposited with Department of History, University of the West Indies, Cave Hill.

Family Structure and Social Change of Caribbeans in Britain Research Project ESRC Award no. L315253009 (2000). Recordings and transcripts deposited with Qualidata Archive, University of Essex.

Barbados Museum and Historical Society. Wealth of a Nation Oral History Project.

\section{Internet}

www.statistics.gov.uk (11 July 2005)

www.caribbeanedu.com/elections/bb07.asp

\section{Doctoral thesis}

Giovannetti, Jorge. Black British Subjects in Cuba: Race, Ethnicity, Nation and Identity in the Migratory Experience 1898-1938 (Ph.D. thesis, University of North London, 2002).

\section{Other}

The Marcus Garvey and Universal Negro Improvement Association Papers, Caribbean Series Manuscript: Barbados documents. The Marcus Garvey and UNIA Papers Project, Los Angeles.

Bobst Library, New York University: Communist Party USA. Records of the CPUSA 1930.

\section{Secondary sources}

Abrahams, R. D. 'The shaping of folklore traditions in the British West Indies' Journal of Inter-American Studies, 9:3 (Jul. 1967), 456-480.

Anderson, B. Imagined Communities: Reflections on the Origins and Spread of Nationalism (London: Verso, 1983).

Anthias, F., and Yuval-Davis, N. (eds). Woman - Nation - State (Basingstoke: Macmillan 1989).

Baptiste, F. A. The United States and West Indian Unrest, 1918-1939 (St Augustine, ISER, University of the West Indies, Working Paper no. 18, n.d.).

Baptiste, F. A. War, Cooperation and Conflict: The European Possessions in the Caribbean 1939-1945 (New York and London: Greenwood, 1988). 


\section{B I B LIO G R A P H Y}

Barriteau, V. E. Confronting Power, Theorising Gender: Interdisciplinary Perspectives in the Caribbean (Kingston: University of the West Indies Press, 2003).

Barriteau, V. E. The Political Economy of Gender in the Twentieth Century Caribbean (Basingstoke: Palgrave, 2001).

Barrow, C. (ed.). Caribbean Portraits: Essays on Gender Ideologies and Identities (Kingston: Ian Randle Publishers, 1998).

Bauer, O. 'The Nation' (1924), reprinted in G. Balakrishnan (ed.), Mapping the Nation (London: Verso, 1996).

Beckles, H. McD. A History of Barbados: From Amerindian Settlement to Nation State (Cambridge: Cambridge University Press, 1990).

Beckles, H. McD., and Shepherd, V. A. (eds). Caribbean Freedom: Economy and Society from Emancipation to the Present (Kingston: Ian Randle Publishers 1993).

Beckles, H. McD., and Stoddart, B. (eds). Liberation Cricket: West Indies and Cricket Culture (Manchester: Manchester University Press, 1995).

Beckles, H. McD. The Development of West Indies Cricket: The Age of Nationalism Volume 1 (London: Pluto Press, 1999).

Beckles, H. McD. Chattel House Blues: Making of a Democratic Society in Barbados, from Clement Payne to Owen Arthur (Kingston: Ian Randle, 2004).

Beckles, H. McD. Great House Rules: Landless Emancipation and Workers' Protest in Barbados 1838-1938 (Kingston, Ian Randle 2004).

Bell, W. 'Attitudes of Jamaican elites towards the West Indies Federation', Annals of the New York Academy of Sciences, 83:5 (Jan. 1960), 862-879.

Benn, D. The Caribbean: An Intellectual History 1774-2003 (Kingston: Ian Randle Publishers, 2004).

Bhabha, H. (ed.). Nation and Narration (New York and London: Routledge, 1990).

Blanshard, P. Democracy and Empire in the Caribbean (New York: The Macmillan Company, 1947).

Blom, I., Hagemann, K., and Hall, C. (eds). Gendered Nations: Nationalisms and Gender Order in the Long Nineteenth Century (Oxford: Berg, 2000).

Bolland, O. N. The Politics of Labour in the British Caribbean (Kingston: Ian Randle Publishers, 2001).

Bolland, O. N. (ed.). The Birth of Caribbean Civilisation: A Century of Ideas about Culture and Identity, Nation and Society (Kingston: Ian Randle Publishers, 2004).

Bolles, A. L. We Paid Our Dues (Washington DC: Howard University Press, 1996).

Bonner, D. Review of Walter F. Pitts Old Ship of Zion: The Afro-Baptist Ritual in the African Diaspora, in American Anthropologist, 98:2 (1996), 452-453.

Braithwaite, L. Colonial West Indian Students in Britain (Kingston: University of the West Indies Press, 2001).

Brathwaite, E. K. History of the Voice: the Development of Nation Language in Caribbean Anglophone Poetry (London and Port of Spain: New Beacon Books, 1984).

Brereton, B. Race Relations in Trinidad 1870-1900 (Cambridge: Cambridge University Press, 1979).

Brereton, B. (ed.). General History of the Caribbean, Vol. V. The Caribbean in the Twentieth Century (Paris: UNESCO/London: Macmillan, 2004).

Browne, D. 'The era of working class political organization in early $20^{\text {th }}$ century Barbados: U.N.I.A. and WMA', Seminar Paper no. 6, Department of History, University of the West Indies, 1988-89.

Burton, R. D. E. 'Names and naming in Afro-Caribbean culture', New West Indian Guide, 73:1-2 (1999), 35-58.

Butt-Thompson, F. W. West African Secret Societies: Their Organisation, Officials and Teaching (London: Witherby, 1929).

Carew, J. 'The West Indian artist in the contemporary world', Phylon, 13:2 (1952). 


\section{B IB LIOG R A PHY}

Carmichael, T. A. (ed.). Barbados: Thirty Years of Independence (Kingston: Ian Randle Publishers, 1996).

Carr, R. Black Nationalism in the New World: Reading the African American and West Indian Experience (Durham, North Carolina: Duke University Press, 2003).

Cassells, P. (ed.). The Giddens Reader (London: Macmillan 1993).

Chamberlain, M. 'Renters and farmers: the Barbadian plantation tenantry system 19171937', Journal of Caribbean History, 24:2 (1990), 195-225.

Chamberlain, M. 'The family as model and metaphor in Caribbean migration' Journal of Ethnic and Migration Studies, 25:2 (1999), 251-266.

Chamberlain, M. Narratives of Exile and Return (New Brunswick: Transaction Publishers, 2004 [1997]).

Chamberlain, M. Family Love in the Diaspora: Migration and the Anglo-Caribbean Experience (New Brunswick: Transaction Publishers/Kingston: Ian Randle Publishers, 2006).

Clarke, A. Growing Up Stupid Under the Union Jack (Kingston: Ian Randle Publishers, 2003 [1980]).

Clarke, C. 'Insularity and identity in the Caribbean', Geography 61:1 (1976), 8-16.

Cohen, R. Global Diasporas: An Introduction (London: UCL Press), 1997.

Coombs, O. (ed.). Is Massa Day Dead? Black Moods in the Caribbean (New York: Anchor, 1974).

Corkran, H. Jr. Patterns of International Co-operation in the Caribbean 1942-1969 (Dallas: Southern Methodist University Press, 1970).

Craton, M. A History of the Bahamas (London: Collins, 1962).

Crawford, W. I Speak for the People: The Memoirs of Wynter Crawford, edited by W. K. Marshall (Kingston: Ian Randle Publishers, 2003).

Cummins, A., Thompson, A., and Whittle. N. Art in Barbados (Kingston: Ian Randle Publishers, 1999).

Cummins, A. 'Caribbean museums and national identity', History Workshop Journal, 58 (2004), 225-246.

Daniel, G. T. 'Labor and nationalism in the British Caribbean', Annals of the American Association of Political and Social Sciences, 310 (1957), 162-171.

Darwin, J. 'British decolonization since 1945: A pattern or a puzzle?', Journal of Imperial and Commonwealth History, 12:2 (1984), 187-209.

Davin, A. 'Imperialism and motherhood', History Workshop Journal, 5 (1978), 9-66.

Deutsch, K. W. Nationalism and Social Communication: An Inquiry into the Foundations of Nationality (Cambridge, Mass.: Technology Press of MIT, 1953).

Deutsch, K. W. 'The Growth of nations: Some recurrent patterns of political and social integration', World Politics, 5:2 (1955), 168-195.

Diawara, M. 'Englishness and blackness: cricket as discourse on colonialism', Callalou, 13: 4 (Autumn 1990), 830-844.

Duncan, N. 'National Development and Democratization in the Eastern Caribbean'. Paper presented at Democracy and Development in the Caribbean, part III. Inter-American Politics Seminar Series, Center for Inter-American Relations (Jan 12-16, 1979).

Drayton, R., and Andaiye (eds). Conversations: George Lamming - Essays, Addresses and Interviews, 1953-1990 (London: Karia Press, 1992).

Du Bois, W. E. The Souls of Black Folk (New York: Signet, 1995 [1903]).

Edmondson, B. (ed.). Caribbean Romances: The Politics of Regional Representation (Charlottesville and London: University Press of Virginia, 1999).

Edmondson, B. Making Men: Gender, Literary Authority and Women's Writing in Caribbean Narrative (Durham and London: Duke University Press, 1999).

Edwards, B. H. The Practice of Diaspora: Literature, Translation and the Rise of Black Internationalism (Cambridge, Mass.: Harvard University Press, 2003). 


\section{B IB LIOG R A PHY}

Fanon, F. Black Skin, White Masks (London: Paladin, 1970).

Fenwick, E. The Fate of the Fenwicks, ed. A. F. Webb (London, 1927).

Fog Olwig, K. Caribbean Journeys: An Ethnography of Migration and Home in Three Family Networks (London and Durham: Duke University Press, 2007).

Foucault, M. Discipline and Punish: The Birth of the Prison (Harmondsworth: Penguin 1991[1977]).

Fraser, C. 'The twilight of colonial rule in the British West Indies', Journal of Caribbean History, 30:1-2 (1996), 1-27.

Fraser, C. Ambivalent Anti-Colonialism: The United States and the Genesis of West Indian Independence, 1940-1964 (Westport: Greenwood Press, 1994).

Froude, J. A. The English in the West Indies; or, the Bow of Ulysses (London: Longmas, Green, and Co., 1888).

Gellner, E. Nations and Nationalism (Oxford: Oxford University Press, 1983).

Gilroy, P. The Black Atlantic: Modernity and Double Consciousness (London: Verso 1993).

Goldsworthy, D. 'Keeping change within bounds: aspects of colonial policy during the Churchill and Eden governments, 1951-57', Journal of Imperial and Commonwealth History, 18:1 (Jan. 1990), 81-108.

Gomes, A. The Federation of the West Indies (London: Commonwealth Parliamentary Association, 1950).

Gooding, E. The West Indies at the Crossroads (Cambridge, Mass.: Schenkman Publishing Company Inc., 1981).

Goulbourne, H. (ed.) Black Politics in Britain (Aldershot: Avebury 1990).

Goveia, E. V. Slave Society in the British Leeward Islands at the End of the Eighteenth Century (New Haven and London: Yale University Press, 1965).

Goveia, E. V. A Study on the Historiography of the British West Indies to the End of the Nineteenth Century (Washington D.C., Howard University Press, 1980 [1956]).

Greenbaum, S. 'Economic cooperation among urban industrial workers: rationality and community in an Afro-Cuban mutual aid society, 1904-1927', Social Science History, 17:2 (1993),173-193.

Griffith, G. 'Deconstructing nationalism: Henry Swanzy, Caribbean Voices and the development of West Indian literature', Small Axe, 5:2 (2001), 1-20.

Halbwachs, M. On Collective Memory (Chicago and London: University of Chicago Press, 1992 [1952]).

Haniff, Y. Speeches of Errol Barrow (London: Hansib Publications Limited, 1987).

Harney, S. Nationalism and Identity: Culture and the Imagination in a Caribbean Diaspora (Kingston, The Press, the University of the West Indies, 1996).

Harrison, J. 'A survey of painting in the British Caribbean', Bim, 4:11 (1949), 221-24.

Heinlein, F. British Government Policy and Decolonisation, 1945-1963: Scrutinising the Official Mind (London: Frank Cass, 2002).

Henry, K. S. 'Language, culture and society in the Commonwealth Caribbean', Journal of Black Studies, 7:1 (Sept. 1976), 79-94.

Henry, K. S., 'The Black political tradition in New York: a conjunction of political cultures', Journal of Black Studies, 7:4 (June 1977), 455-484.

Henry, P. Caliban's Reason: Introducing Afro-Caribbean Philosophy (New York: Routledge, 2000).

Higman, B. W., Slave Populations of the British Caribbean 1807-1834 (Kingston: The Press, The University of the West Indies, 1995).

Higman, B. W. (ed.). The General History of the Caribbean Vol. VI: Methodology and Historiography of the Caribbean (London and Oxford, UNESCO Publishing/Macmillan Caribbean, 1999).

Hodgkin, K., and Radstone, S. (eds). Contested Pasts: The Politics of Memory (Routledge: 


\section{B I B LIO G R A P H Y}

2003).

Holland, R. F. 'The Imperial factor in British strategies from Attlee to Macmillan, 19451963', Journal of Imperial and Commonwealth History, 12:2 (Jan. 1984), 165-185.

Howe G. D., and Marshall D. D. (eds). The Empowering Impulse: The Nationalist Tradition of Barbados (Mona: Canoe Press, 2001).

Howe, G. D. Race, War and Nationalism: A Social History of West Indians in the First World War (Kingston: Ian Randle/Oxford: James Currey, 2002).

Hoyos, A. The Rise of West Indian Democracy: The Life and Times of Sir Grantley Adams (Bridgetown: Advocate Press, 1963).

Irele, A. 'Negritude or black cultural nationalism', Journal of Modern African Studies, 3:3 (1965), 321-348.

Ishemo, S. L. 'From Africa to Cuba: An historical analysis of the sociedad secreta Abakuá (Ñañiguismo)', Review of African Political Economy, 92 (2002), 253-272.

James, C. L. R. The Case for West Indian Self Government (London, 1933).

James, C. L. R. An Analysis of the Political Situation in Barbados (n.p., 1958).

James, C. L. R. Beyond a Boundary (London: Stanley Paul \& Co., 1963).

James, C. L. R. The Black Jacobins (London, Alison and Busby, 1984).

James, W. Holding Aloft the Banner of Ethiopia: Caribbean Radicalism in Early Twentieth Century America (London: Verso, 1998).

Johnson, H. 'The West Indies and the Conversion of the British Official Classes to the Development Idea', Journal of Commonwealth and Comparative Politics, 15:1 (Mar. 1979), 55-83.

Johnson, H. "The "Jamaica 300" celebrations of 1955: commemoration in a colonial polity', Journal of Imperial and Commonwealth History, 26:2 (1998), 120-137.

Johnson, H. The Bahamas in Slavery and Freedom (Kingston: Ian Randle Publishers, 1991).

Jones-Hendrickson, S. B. (ed.). Caribbean Visions: Ten Presidential Addresses of Ten Presidents of the Caribbean Studies Association (Frederikstad, V. I.: Eastern Caribbean Institute, 1990).

Kasinitz, P. Caribbean New York: Black Immigrants and the Politics of Race (Ithaca: Cornell University Press, 1992).

Killingray, D. 'The West Indian Federation and decolonization in the British Caribbean', Journal of Caribbean History, 34:1-2 (2000), 71-88.

Knape, J. 'British foreign policy in the Caribbean basin 1938-1945: Oil, nationalism and relations with the United States', Journal of Latin American Studies, 19:2 (1987), 279-294.

Kuyk, B. M. 'The African derivation of black fraternal orders in the United States', Comparative Studies in Society and History, 25:4 (1983), 559-592.

La Guerre, J. 'The Moyne Commission and the West Indian intelligentsia, 1938-39', Journal of Commonwealth Political Studies, 9:2 (1971), 134-157.

Lamming, G. In the Castle of My Skin (London: Longman, 1953).

Lamming, G. The Pleasures of Exile (London: Michael Joseph, 1960).

Lamming, G. (ed.). On the Canvas of the World (Port of Spain: Institute of the West Indies, 1999).

Lamming, G. Coming, Coming Home: Conversations II (St Martin, Caribbean: House of Nehesi Publishers, 2000).

Lamming, G. The Sovereignty of the Imagination (Kingston: Arawak Publications, 2004).

Lewis, G. K. The Growth of the Modern West Indies (London: MacGibbon and Kee, 1968).

Lewis, L. 'Exploring the folk culture of Barbados through the medium of the folk tale', Caribbean Studies, 23:3-4 (1990), 85-94. 


\section{B IB LIOG R A PHY}

Lewis, R., and Warner-Lewis, M. Garvey: Africa, Europe, the Americas (Kingston: University of the West Indies, Institute of Social and Economic Research, 1986).

Leydesdorff, S., Dawson, G., Burchardt, N., and Ashplant, T. G. (eds). Trauma and Life Stories (London: Routledge 1999).

Long, E. History of Jamaica, Vol. 2 (Montreal and Kingston; London: McGill-Queen's University Press, 2002). Facsimile reprint of edition published by T. Lowndes, London, 1774.

Look Lai, W. Indentured Labour, Caribbean Sugar: Chinese and Indian Migrants to the British West Indies, 1838-1918 (Baltimore and London: The Johns Hopkins University Press, 1993).

Lowenthal, D. 'Black power in the Caribbean context', Economic Geography, 48 (1972), $116-134$.

Lowenthal, D. (ed.). The West Indian Federation: Perspectives on a New Nation (Westport: Greenwood, 1976 [1961]).

Lynch, L. West Indian Eden: The Book of Barbados (Glasgow: Robert Maclehouse \& Co. Ltd., 1959).

Macmillan, W. M. Warning from the West Indies: A Tract for Africa and Empire (Freeport, New York: Books for Libraries Press, 1936).

Marshall, P. Brown Girl, Brownstones (New York: The Feminist Press, 1981 [1959]).

Marshall, T., McGeary, P., and Thomson, G. Folksongs of Barbados (Bridgetown: Macmarson, 1981).

Marshall, W. K., and Welch, P. (eds). Beyond the Bridge: A Series of Lectures to Commemorate the $375^{\text {th }}$ Anniversary of Bridgetown (Bridgetown: The Barbados Museum and Historical Society/University of the West Indies (Cave Hill), Department of History and Philosophy, 2005).

Martin, J. B. US Policy in the Caribbean (Boulder, Colorado: Westview Press, 1978).

Mayer, T. (ed.). Gender Ironies of Nationalism: Sexing the Nation (London and New York: Routledge, 2000).

McClintock, A., Mufti, A. R., and Shohat, E. Dangerous Liaisons: Gender, Nation and Post-Colonial Perspectives (St Paul: University of Minnesota Press, 1997).

Meehan, K., and Léticée, M. 'A folio of writing from La Revue Indigène (1927-28)', Callaloo, 23:4 (2000), 1377-1390.

Meredith, S. 'Barbadian Tuk Music: Colonial Development and Post-Independence Recontextualisation', British Journal of Ethnomusicology, 12:2 (2003), 81-106.

Mintz, S. W., and Price, R. An Anthropological Approach to the African-American Past: A Caribbean Perspective (Philadelphia: Institute for the Study of Human Issues, 1976).

Mintz, S. W. Caribbean Transformations (New York: Columbia University Press, 1989).

Mitchell, H. Europe in the Caribbean: The policies of Great Britain, France and the Netherlands towards their West Indian Territories in the Twentieth Century (Edinburgh: W \& R Chambers Ltd, 1963).

Mohammed, P. 'Towards Indigenous feminist theorizing in the Caribbean' Feminist Review, 59 (Summer 1998), 3-33.

Mohammed, P. "'But most of all mi love me browning": The emergence in eighteenth and nineteenth century Jamaica of the emergence of the Mulatto woman as the desired', Feminist Review, no. 65 (Summer 2000), 22-48.

Mohammed, P. Imaging the Nation (Basingstoke: Macmillan Caribbean, 2007).

Mordecai, J. The West Indies: The Federal Negotiations (London: George Allen and Unwin, 1968).

Moskos, C. C. The Sociology of Political Independence: A Study of Nationalist Attitudes Among West Indian Leaders (Cambridge, Mass.: Schenkman Publishing Co. Inc., 1967). 


\section{B IB L IO G R A PHY}

Munro, T. The Politics of Constitutional Decolonisation (Kingston: University of the West Indies, Institute of Social and Economic Research, 1972).

Newton, V. The Silver Men: West Indian Labour Migration to Panama 1850-1914 (Kingston: University of the West Indies, Institute of Social and Economic Research, 1987).

Parker, J. "Capital of the Caribbean;" The African American-West Indian "Harlem nexus" and the transnational drive for black freedom 1940-1948', Journal of African American History, 89:2 (Spring 2004), 98-117.

Parker, J. C. Brother's Keeper: The United States, Race and Empire in the British Caribbean, 1937-1962 (New York: Oxford University Press, 2008).

Passerini, L. (ed.). Memory and Totalitarianism (New Brunswick: Transaction Publishers, 2005 [1992]).

Patterson, P. J. The Sociology of Slavery (London: MacGibbon and Kee, 1967).

Perkins, D. The United States and the Caribbean (Cambridge, Mass.: Harvard University Press, 1966).

Pizarro A., and Zammit, J. A. 'Reflections on the historiography of Caribbean literature', Callalou, 34 (1988), 176.

Plummer, B. G. Rising Wind: Black Americans and US Foreign Affairs 1935-1960 (Chapel Hill and London: University of North Carolina Press, 1996).

Poole, B. L. The Caribbean Commission: Background of Co-operation in the West Indies (Columbia: University of South Carolina Press, 1951).

Post, K. Arise Ye Starvelings: The Jamaican Labour Rebellion of 1938 and its Aftermath (The Hague and Boston: Nijhoff, 1978).

Proctor, J. H., Jr. 'British West Indian society and government in transition 1920-60', in D. Lowenthal and L. Comitas, The Aftermath of Sovereignty: West Indian Perspectives (New York: Anchor Books, 1973).

Proctor, R. 'Early developments in Barbadian education', Journal of Negro Education, 49:2 (Spring 1980), 184-185.

Putnam, L. The Company They Kept: Migrants and the Politics of Gender in Caribbean Costa Rica, 1870-1960 (Chapel Hill and London: The University of North Carolina Press, 2002).

Radstone, S., and Hodgkin, K. Regimes of Memory (London: Routledge, 2003).

Reddock, R. Elma François (London: New Beacon Books, 1988).

Reddock, R. Women, Labour and Politics in Trinidad and Tobago: A History (London: Zed Books, 1994).

Reddock, R. Women's Movements and Organisations in the Process of Revolutionary Transformation: The Case of Grenada (n.p., 1983).

Reicher, S. D., and Hopkins, N. Self and Nation (London: Sage, 2001).

Reid, I. D. The Negro Immigrant: His Background, Characteristics and Social Adjustment 1899-1937 (New York: AMS Press, 1939).

Richardson, B. Panama Money in Barbados 1900-1920 (Knoxville: University of Tennessee Press, 1985).

Ringen, S. The Liberal Vision and Other Essays in Democracy and Progress (Oxford: The Bardwell Press, 2007).

Ringen, S. Power, Authority and Leadership, Working paper, University of Oxford, Feb. 2009.

Roach Pierson, R. (ed.). Nation, Empire, Colony: Historicising Gender and Race (Bloomington: Indiana University Press, 1998).

Roberts, G. W. The Population of Jamaica (Cambridge: Cambridge University Press, 1957).

Rohlehr, G. Calypso and Society in Pre-Independence Trinidad (Tunapuna: Gordon Rohlehr, 1990). 


\section{B I B LIO G R A P H Y}

Rose, S. Gender, Citizenships and Subjectivities (Oxford: Blackwell, 2002).

Said, E. Culture and Imperialism (London: Chatto \& Windus, 1993).

Schwarz, B. (ed.). West Indian Intellectuals in Britain (Manchester: Manchester University Press, 2003).

Scott, D. Conscripts of Modernity: The Tragedy of Colonial Enlightenment (Durham and London: Duke University Press, 2004).

Scott, J. C. The Moral Economy of the Peasant: Rebellion and Subsistence in Southeast Asia (New Haven and London: Yale University Press, 1976).

Scott, J. C. Domination and the Arts of Resistance: Hidden Transcripts (New Haven and London: Yale University Press, 1990).

Shepherd, V. A., Brereton, B., and Bailey, B. (eds). Engendering History: Caribbean Women in Historical Perspective (Kingston: Ian Randle Publishers, 1995).

Shepherd, V. A. Women in Caribbean History (Kingston: Ian Randle Publishers, 1999).

Sherlock, P., and Nettleford, R. The University of the West Indies: A Caribbean Response to the Challenge of Change (London: Macmillan, 1990).

Simey, T. Welfare and Planning in the West Indies (Oxford: The Clarendon Press, 1946).

Smith, A. The Ethnic Origins of Nations (Oxford: Blackwell, 1986).

Smith, R. Jamaican Volunteers in the First World War: Race, Masculinity and the Development of National Consciousness (Manchester: Manchester University Press, 2004).

Springer, H. W. Reflections on the Failure of the First West Indian Federation (Cambridge, Mass.: Center for International Affairs, Harvard University Press, 1962).

Stepan, N. The Hour of Eugenics: Race, Gender and Nation in Latin America (Ithaca: Cornell University Press, 1996).

Stephens, M. A. Black Empire: The Masculine Global Imaginary of Caribbean Intellectuals in the United States, 1914-1962 (Durham and London: Duke University Press, 2005)

Summerfield, P. Reconstructing Women's Wartime Lives (Manchester: Manchester University Press, 1998).

Sutton, C. R., and Chaney, E. M. (eds). Caribbean Life in New York City: Sociocultural Dimensions (New York: Center for Migration Studies of New York, 1994).

Sutton, C. R. (ed.). Revisiting Caribbean Labour (Kingston/Miami: Ian Randle Publishers, 2005).

Szulc, T. (ed.). The United States and the Caribbean (Englewood Cliff: Prentice-Hall, Inc., 1971).

Thomas, J. J. Froudacity: West Indian Fables (London: New Beacon Books, 1969 [1889]).

Thomas, R. The Trinidad Labour Riots of 1937: Perspectives 50 Years Later (St Augustine: Extra Mural Studies Unit, University of the West Indies, 1987).

Thompson, E. P. Customs in Common (London: The Merlin Press, 1991).

Titmuss, R. The Philosophy of Welfare (London: Allen and Unwin, 1987).

Trotman, D. Crime in Trinidad: Conflict and Control in a Plantation Society 1838-1900 (Knoxville: University of Tennessee Press, 1986).

Turner, B. W., and Moore Turner, J. Richard B. Moore, Caribbean Militant in Harlem (Bloomington and Indianapolis: Indiana University Press/London: Pluto Press, 1988).

Von Eschen, P. M. Race Against Empire: Black Americans and Anti-colonialism, 19371957, (Ithaca, NY: Cornell University Press, 1997).

Wallace, E. The British Caribbean: From the Decline of Colonialism to the End of Federation (Toronto: University of Toronto Press, 1977).

Walcott, D. The Star Apple (New York: Farrar, Strauss and Giroux, 1977).

Watkins-Owens, I. Blood Relations: Caribbean Immigrants and the Harlem Commu- 


\section{B IB LIOG R A PHY}

nity, 1900-1930 (Bloomington: Indiana University Press, 1996).

Werbner, R. (ed.). Memory and the Postcolony: African Anthropology and the Critique of Power (London: Zed Books, 1998).

Williams, E. E. 'Massa Day Done', Public Lecture at Woodford Square, 22 Mar. 1961, in Callalou, 20:4 (1997), 725-730.

Worrell, R. Pan Africanism in Barbados: An Analysis of the Activities of the Major Twentieth Century Pan-African Formations in Barbados (Barbados: Rodney Worrell/ Gail Clarke, 2002).

Yuval-Davis, N. Gender and Nation (London: Sage, 1997). 